\title{
PENGARUH PENGHARGAAN FINANSIAL DAN PERTIMBANGAN PASAR KERJA TERHADAP KEPUTUSAN PEMILIHAN PROFESI ALUMNI SARJANA EKONOMI SYARIAH DI BOGOR
}

\author{
Astrini $^{1}$, Tuti Kurnia ${ }^{2}$ \\ ${ }^{1}$ Program Studi Ekonomi Syariah, Universitas Djuanda, astrini@gmail.com \\ ${ }^{2}$ Program Studi Ekonomi Syariah, Universitas Djuanda, tuti.kurnia@unida.ac.id
}

\begin{abstract}
This study aims to determine the effect of financial rewards and labor market considerations on the decisions of sharia economics graduates in choosing a profession. The research method used is descriptive with a quantitative approach using logistic regression analysis techniques. The population of this study is the 2017-2019 sharia economics graduate consisting of Djuanda University, Bogor Agricultural University, and Ibn Khaldun University with a sample of 86 respondents. The types of data used are primary and secondary data using questionnaires and interviews. The results show that financial rewards have not effect on the decision of sharia economics graduates in choosing a profession. This is because sharia economics graduates prefer work experience as the main choice in professional selection compared to financial awards. The labor market considerations have a significance effect on the decision of sharia economics graduates in choosing a profession. This means that a good job market can provide assurance for future graduates of Islamic economics undergraduate.
\end{abstract}

Keywords: Financial Awards, Labor Market Considerations, Professional Selection

\begin{abstract}
ABSTRAK
Penelitian ini bertujuan untuk mengetahui pengaruh penghargaan finansial dan pertimbangan pasar kerja terhadap keputusan alumni sarjana ekonomi syariah dalam memilih profesi. Metode penelitian yang digunakan adalah deskriptif dengan pendekatan kuantitatif dengan menggunakan teknik analisis regresi logistik. Populasi dari penelitian ini yaitu alumni sarjana ekonomi syariah tahun 2017-2019 dari Universitas Djuanda, Institut Pertanian Bogor, dan Universitas Ibn Khaldun dengan sampel 86 responden. Jenis data yang digunakan yaitu data primer dan data sekunder dan menggunakan teknik penyebaran kuesioner dan wawancara. Hasil menunjukkan bahwa penghargaan finansial tidak berpengaruh terhadap keputusan alumni sarjana ekonomi syariah dalam pemilihan profesi. Hal tersebut disebabkan alumni sarjana ekonomi syariah lebih memilih pengalaman kerja sebagai pilihan utama dalam pemilihan profesi dibandingkan dengan penghargaan financial sedankan, pertimbangan pasar kerja berpengaruh signifikan terhadap keputusan alumni sarjana ekonomi syariah dalam pemilihan profesi. Hal tersebut berarti bahwa pasar kerja yang baik dapat memberikan jaminan bagi alumni sarjana ekonomi syariah di masa depan.
\end{abstract}

Kata kunci: Pemilihan Profesi, Penghargaan Finansial, Pertimbangan Pasar Kerja 


\section{PENDAHULUAN}

Perkembangan sektor ekonomi syariah semakin bersaing di taraf global. Berkembangnya sektor ekonomi syariah menjadikan persaingan bagi alumni sarjana ekonomi syariah di dunia kerja semakin ketat untuk mendapatkan pekerjaan. Oleh karena itu alumni sarjana ekonomi syariah beperan penting dalam pengembangan perekonomian syariah di Indonesia. Tersedianya peluang pekerjaan pada lembaga keuangan syariah bukan hanya ditempati oleh alumni sarjana ekonomi syariah, akan tetapi ditempati juga oleh alumni sarjana dari non ekonomi syariah. Adanya persaingan antar sarjana menyebabkan peluang pasar kerja untuk alumni sarjana ekonomi syariah semakin kompetitif, sehingga tidak semua alumni ekonomi syariah bekerja sesuai jurusan.

Berdasarkan hasil penelitian Deswita dan Astuti (2015) bahwa 50 persen alumni sarjana ekonomi syariah bekerja sesuai jurusan, 21 persen tidak sesuai lulusan sedangkan sisanya 29 persen keahlian atau jurusan alumni sarjana yang terkait dengan bidang pekerjaannya. Persaingan dunia kerja bisa dilihat dari para alumni sarjana ekonomi syariah dari beberapa Perguruan Tinggi di Bogor yaitu dari Institut Pertanian Bogor (IPB), Sekolah Tinggi Ekonomi Islam Tazkia (STEI TAZKIA), Universitas Djuanda (UNIDA), Universitas Ibn Khaldun (UIKA), Institut Agama Islam Sahid (INAIS) dan Institut Agama Islam Nasional Laa Roiba (IAIN Laa Roiba).

Kepala Disnakertrans Kota Bogor menyebutkan bahwa sekitar 1.500 lowongan kerja telah disiapkan untuk semua alumni sarjana Perguruan Tinggi (Haryudi, 2018). Alumni sarjana ekonomi syariah bersaing dengan alumni sarjana non ekonomi syariah dalam mendapatkan kesempatan kerja, sementara yang masuk ke industri syariah itu tidak hanya dari alumni sarjana ekonomi syariah saja akan tetapi juga dari alumni sarjana non ekonomi syariah. Alumni sarjana ekonomi syariah tidak selalu bekerja di lingkungan ekonomi syariah. Sebagian alumni sarjana ekonomi syariah di Bogor ada yang berstatus kerja pada bidang ekonomi syariah seperti pada lembaga atau badan keuangan syariah atau di dunia bisnis. Akan tetapi ada juga alumni sarjana ekonomi syariah dengan status bekerja di luar bidang ekonomi syariah, misalnya sebagian alumni sarjana ekonomi syariah Universitas Djuanda dengan status bekerja dalam bidang IT dan tenaga pendidik, begitupun sebagian alumni sarjana ekonomi syariah Universitas Ibn Khaldun yang bekerja pada lembaga atau badan keuangan non syariah dan pada bidang konstruksi. 
Pemilihan pekerjaan dipengaruhi oleh berbagai faktor, salah satunya oleh faktor finansial atau yang disebut dengan gaji. Gaji merupakan faktor yang menjadi salah satu pertimbangan dalam menentukan suatu pekerjaan. Berdasarkan penelitian Juliansah dan Suryaputri (2016), penghargaan finansial memberikan pengaruh positif untuk memilih karir profesi. Penghargaan finansial atau yang disebut dengan gaji menjadi daya tarik seseorang dalam mempertimbangkan profesi. Sedangkan penelitian Ilyas dan Dary (2017) variabel penghargaan finansial menunjukkan tidak adanya pengaruh untuk memilih profesi. Ada variabel lain yang lebih berpengaruh untuk memilih profesi.

Salah satu permasalahan bagi alumni sarjana ekonomi syariah untuk memilih profesi yaitu persaingan di dalam dunia kerja. Hal yang menjadi penyebabnya yaitu karena lowongan pekerjaan yang terbatas. Tidak hanya terbuka untuk alumni sarjana ekonomi syariah, akan tetapi lowongan pekerjaan juga tesedia untuk semua alumni sarjana di semua bidang. Terbatasnya lowongan pekerjaan bagi alumni sarjana ekonomi syariah menjadikan sebagian alumni sarjana ekonomi syariah memilih untuk bekerja di luar dari bidang ekonomi syariah. Beberapa alumni sarjana ekonomi syariah dengan status bekerja di luar bidang ekonomi syariah disebabkan oleh berbagai pertimbangan, misalnya pertimbangan pasar kerja yang merupakan salah satu pertimbangan untuk memilih profesi. Semakin mudah informasi diakses maka semakin besar peluang alumni sarjana ekonomi syariah untuk mendapatkan pekerjaan. Informasi yang luas memberikan peluang bagi alumni sarjana ekonomi syariah untuk mendapatkan pekerjaan.

Penelitian mengenai pengaruh penghargaan finansial dan pertimbangan pasar kerja dalam pemilihan profesi perlu diteliti dengan tujuan untuk mengetahui pengaruh variabel di atas terhadap keputusan alumni sarjana ekonomi syariah Universitas Djuanda Bogor untuk memilih profesi agar memudahkan alumni sarjana ekonomi syariah untuk memilih suatu pekerjaan pada bidang ekonomi syariah dan mempertimbangkan gaji yang sesuai dengan bidangnya.

\section{LITERATURREVIEW}

\section{Pengambilan Keputusan terhadap Pemilihan Profesi}

Pengambilan keputusan adalah suatu alternatif dalam proses pemilihan untuk menyelesaikan permasalahan dari suatu keputusan (Raihan, 2016). Menurut Erisandi dalam 
Firdaus (2017) keputusan adalah pilihan atau yang diartikan sebagai pemilihan tujuan termasuk metode dalam mencapai tujuan tersebut, di tingkat perorangan atau tingkat kolektif. Keputusan berkaitan dengan proses yang merupakan proses akhir yang dinamis, yang disebut dengan pengambilan keputusan.

Tahapan-tahapan dalam mengambil keputusan menurut Raihan (2016) adalah pertama, pendefinisian masalah secara tepat untuk mengambil keputusan sehingga dapat menemukan faktor-faktor yang terkait yang dapat menjawab pertanyaan-pertanyaan dalam masalah tersebut berdasarkan $5 \mathrm{~W}+1 \mathrm{H}$ kemudian dilakukan pengumpulan data dan hasil analisis. Pertanyaan-pertanyaan di atas tidak dapat dijawab dengan asumsi semata, namun perlu dilakukan penelitian yang lebih lanjut mengenai informasi masalah tersebut. Data dikumpulkan dengan teknik observasi, wawancara, angket, studi dokumen dan sebagainya.

Tahapan kedua yaitu penentuan alternatif. Dapat dilakukan dengan menentukan berbagai alternatif-alternatif yang berkaitan dengan permasalahan. Tahapan ini dapat dilakukan dengan menganalisa masing-masing pendekatan, strategi, atau teknik-teknik yang telah ditawarkan dari kelebihan dan kekurangannya.

Tahapan selanjutnya yaitu pemilihan alternatif terbaik untuk menjalankan keputusan yang telah dihasilkan dan diakhiri dengan memberikan nilai dari hasil yang dicapai. Hasil dari keputusan itu menjadi referensi bagi pengambilan keputusan pada masa mendatang bagi pimpinan berdasarkan kelebihan maupun kekurangan.

\section{Penghargaan Finansial}

Penghargaan finansial yaitu sebuah penghargaan dalam bentuk finansial. Aspek tersebut merupakan pertimbangan seseorang dalam bekerja agar memperoleh gaji. Penghargaan finansial merupakan daya tarik utama karyawan dalam memperoleh kepuasan sebagai wujud imbal balik dari pekerjaan (Wicaksono dan Aisyah, 2017). Menurut Rivai dalam Arismutia (2017) menguraikan komponen-komponen dalam penghargaan finansial yaitu sebagai berikut:

a. gaji, ialah bentuk balas jasa berupa penerimaan uang kepada karyawan sebagai suatu konsekuensi dari kedudukan dengan memberikan tenaga serta pikirannya untuk mencapai tujuan suatu perusahaan atau sebagai imbal jasa yang tetap dari perusahaan untuk seseorang dari keanggotaannya. 
b. upah, ialah imbalan dalam bentuk finansial yang diberikan secara langsung kepada karyawan berdasarkan perolehan jumlah jam kerja, hasil kerja atau pelayanan yang diberikan karyawan. Nilai upah dapat berubah sesuai dengan nilai yang diberikan.

c. insentif ialah imbalan yang diberikan secara langsung terhadap karyawan karena usahanya melebihi dari penentuan target, dapat menghemat biaya dan meningkatkan produktivitas. Insentif merupakan suatu kompensasi yang tetap berdasarkan kinerja.

d. fringe benefit ialah kompensasi tambahan dari suatu perusahaan kepada karyawannya berdasarkan kebijakan perusahaan dalam meningkatkan kesejahteraan seluruh karyawan. Misalnya dalam bentuk: tunjangan, uang pensiun, asuransi, dan lain sebagainya.

Islam menggambarkan upah dan gaji secara komprehensif. Dalam firmannya, Allah SWT menegaskan mengenai imbalan ini di dalam QS. At Taubah [9] ayat 105 yaitu:

"Dan katakanlah: "Bekerjalah kamu, maka Allah dan Rasul-Nya serta orang-orang mu'min akan melihat pekerjaanmu itu, dan kamu akan dikembalikan kepada Allah Yang Mengetahui akan ghaib dan yang nyata, lalu diberikan-Nya kepada kamu apa yang kamu kerjakan”.

\section{Pertimbangan Pasar Kerja}

Pertimbangan pasar ialah salah satu faktor pertimbangan alumni sarjana untuk memilih profesi. Dalam pemilihan pekerjaan, biasanya alumni sarjana memilih pekerjaan berdasarkan informasi yang diperoleh. Sehingga pekerjaan yang mudah diakses banyak diminati oleh alumni sarjana (Jaya dan Harimurti, 2018). Pertimbangan pasar kerja memiliki hubungan yang erat antara pertimbangan pasar kerja dengan pekerjaan yang diakses pada masa mendatang. Luasnya pasar kerja dalam sebuah pekerjaan akan lebih diminati oleh para pekerja (Juliansah dan Suryaputri, 2016).

Menurut Wheller dalam Arismutia (2017) pertimbangan pasar kerja terdiri dari empat aspek, yaitu tersedianya lapangan pekerjaan, keamanan kerja, fleksibilitas karis dan kesempatan promosi. Wheeler menyatakan mahasiswa dengan jurusan bisnis, psikologi, serta pendidikan menyebutkan bahwa suplai kerja lebih baik dibandingkan dengan bisnis lain. Aspek keamanan ialah faktor di mana profesi yang diperoleh dapat bertahan dengan jangka waktu yang panjang dalam arti bukan profesi sementara, tetapi juga dapat berlanjut sampai waktu pensiun. Aspek lainnya adalah pilihan karir yang lebih fleksibel dapat membantu karyawan agar tidak berada pada kondisi yang stagnasi dan membutuhkan perbaharuan pengetahuan dan pelatihan secara terus menerus. selanjutnya, aspek kesempatan promosi yaitu 
proses berpindahnya jenjang karir ke arah yang lebih tinggi yang disertai dengan naiknya tanggung jawab serta imbalan dengan harapan agar posisinya meningkat sesuai dengan prestasi yang dimiliki untuk meningkatkan kualitas kerja, mewakili aspek penting dari sistem seleksi dan mengurangi turnover.

\section{Alumni Sarjana Ekonomi Syariah}

Kompetensi yang diperoleh alumni sarjana ekonomi syariah selama bangku perkuliahan dapat diterapkan dan mendukung pekerjaan mereka dalam dunia kerja, seperti skill atau kemampuan dalam menyelesaikan tugas (tanggung jawab), komputer (teknologi informasi), sikap profesional dalam bekerja, beradaptasi baik dengan lingkungan kerja, menguasai dasardasar akuntansi, perbankan syariah, dan manajemen syariah, menguasai kegiatan ekonomi sesuai dengan ajaran Islam, mengembangkan ide-ide, kemampuan berkomunikasi secara serta kemampuan membuat keputusan kreatif dan inovatif, dan mempelajari setiap kejadiankejadian, dan kepercayaan diri serta etos kerja.

Menurut Deswita dan Astuti (2015) para alumni sarjana ekonomi syariah diharapkan tidak saja akan memiliki kemampuan ilmiah yang cukup tinggi tentang ilmu ekonomi syariah. Mereka diharapkan mampu mengembangkan dan mengelola dunia kerja seperti lembagalembaga bisnis syariah, Lembaga Swadaya Masyarakat (LSM), dan lembaga pendidikan atau penelitian yang berkaitan dengan ekonomi syariah secara keseluruhan.

Widagdo dan Syafrudin (2016) menyatakan bahwa dibutuhkan lembaga pendidikan ekonomi syariah khusus dalam menyiapkan SDI ekonomi syariah yang unggul. Hal itu untuk menciptakan Sumber Daya Insani (SDI) yang kompeten, komprehensif, memadai, juga memiliki integritas tinggi dalam bidang ekonomi, hukum ekonomi syariah dan bisnis, (Widagdo dan Syafrudin, 2016).

Penyiapan SDM ekonomi syariah berkualitas menurut Ibda (2018) tidak terpatri pada Perguruan Tinggi atau fakultas, melainkan pada program studi atau Jurusan. Indikatornya ialah pada akreditasi yang berkualitas, mutu pembelajaran studi, pendidik, kurikulum, prestasi dan karya cipta mahasiswa, penyerapan alumni sarjana, tingkat kepercayaan masyarakat pada program studi tersebut dan kualitas Tri Darma Perguruan Tinggi.

\section{Penelitian Terdahulu}

Penelitian Laka, dkk (2019) menunjukkan tidak adanya pengaruh pertimbangan pasar kerja dan penghargaaan finansial atau gaji untuk memilih karir mahasiswa sebagai akuntan 
publik di PTS di Surakarta. Berbeda dengan Sholichah dan Suparman (2017), terdapat pengaruh yang signifikan terhadap pertimbangan pasar kerja dan penghargaan finansial untuk memilih profesi sebagai akuntan secara simultan dan parsial. Adapun Deswita dan Astuti (2015) kompetensi alumni sarjana ekonomi syariah pada dunia kerja menunjukkan hasil yang positif, sebagian dari alumni sarjana menyatakan kompetensi ekonomi syariah yang mereka miliki sangat bermanfaat dengan dunia kerja.

Berbeda dengan Dary dan Ilyas (2017) hasil penelitiannya menyatakan bahwa variabel gender memiliki pengaruh dalam minat karir mahasiswa akuntansi menjadi akuntan publik dan non akuntan publik pada Perguruan Tinggi Negeri dan Perguruan Tinggi Swasta. Sedangkan variabel pertimbangan pasar kerja dan penghargaan finansial menunjukkan tidak adanya pengaruh dalam minat karir mahasiswa akuntansi menjadi akuntan publik dan non akuntan publik pada Perguruan Tinggi Negeri dan Perguruan Tinggi Swasta. Dengan demikian uraian di atas menggambarkan kerangka pemikiran pada penelitian ini yaitu sebagai berikut:

\section{Gambar 1. Kerangka Pemikiran}

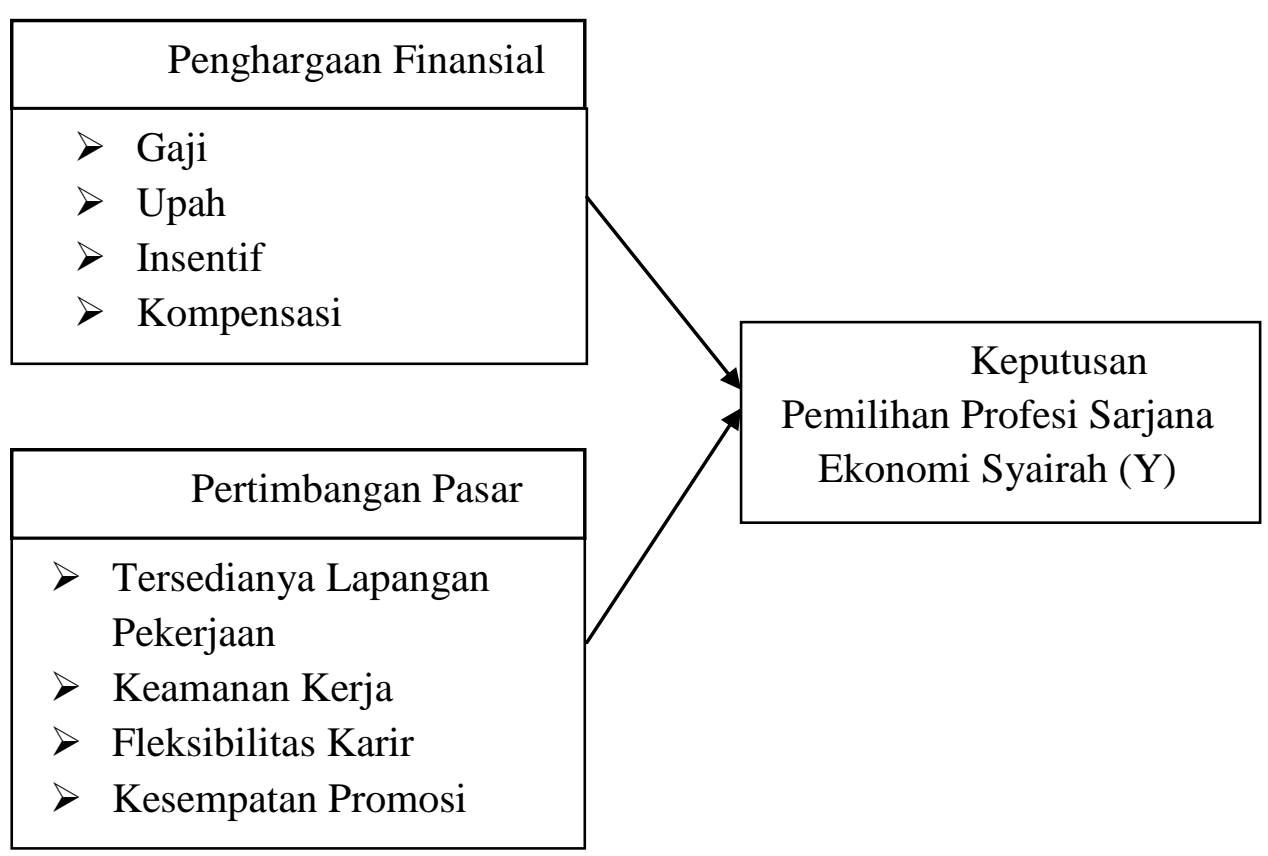




\section{METODE}

\section{Jenis Penelitian, Teknik Sampling dan Teknik Pengambilan Data}

Penelitian ini menggunakan jenis penelitian deskriptif kuantitatif untuk memberikan jawaban yang sistematis terhadap suatu permasalahan agar mendapatkan informasi yang lebih luas dan mendalam mengenai penjelasan secara terperinci tentang pengaruh penghargaan finansial dan pertimbangan pasar kerja dalam keputusan alumni sarjana ekonomi syariah untuk memilih profesi. Pendekatan kuantitatif dianggap sebagai tingkah laku manusia yang dapat diperkirakan dan realitas sosial; dapat diukur dan objektif (Yusuf, 2017).

Teknik pengambilan sampel menggunakan teknik cluster sampling, yaitu pengambilan sampel berdasarkan populasi yang telah ditetapkan. Sehingga penulis mengambil sampel berdasarkan populasi alumni sarjana ekonomi syariah yang ada di Bogor.Jumlah populasi dalam penelitian ini yaitu 597 alumni sarjana ekonomi syariah dari Universitas Djuanda Bogor, Institut Pertanian Bogor, dan Universitas Ibn Khaldun. Kuesioner dibagikan kepada alumni sarjana ekonomi syariah Universitas Djuanda Bogor, Institut Pertanian Bogor, dan Universitas Ibn Khaldun alumni sarjana 2017 sampai dengan alumni sarjana 2019. Maka jumlah sampel ditentukan menjadi 86 responden.

Pengujian hipotesis pada penelitian ini menggunakan regresi logistik dengan berdasarkan pada data nominal sebagai variabel terikat dan data interval sebagai variabel bebas. Formulasi model regresi logistik adalah sebagai berikut:

$$
\begin{aligned}
& \mathrm{Y}=\alpha+\beta_{1} X_{1}+\beta_{2} X_{2}+\mu_{i} \\
& \mathrm{KPP}=\alpha+\beta_{1} \mathrm{PF}+\beta_{2} \mathrm{PPK}
\end{aligned}
$$

\section{HASIL DAN PEMBAHASAN}

\section{Uji Reliabilitas dan Validitas}

Uji reliabilitas dan validitas dilakukan untuk mengetahui ketepatan atau kecermatan setiap pertanyaan yang disajikan pada kuesioner. Uji reliabilitas merupakan suatu proses pengukuran ketepatan terhadap jaminan instrumen yang digunakan (Wadah, 2016).

\begin{tabular}{r|r}
\multicolumn{2}{|c}{ Tabel 1. Nilai Statistik Reliabilitas } \\
\hline $\begin{array}{c}\text { Cronbach's } \\
\text { Alpha }\end{array}$ & $\begin{array}{c}\mathrm{N} \\
\text { of Items }\end{array}$ \\
\hline .742 & 9 \\
\hline
\end{tabular}

Sumber: Olah data, 2020 
Berdasarkan tabel 1 di atas nilai statistik yaitu 0,742 . Hal itu menunjukkan bahwa untuk 9 pertanyaan yang diajukan responden adalah reliabel, karena sesuai dengan dasar 0,742 > 0,60 .

Uji validitas ditentukan berdasarkan koefisien korelasi (r), di mana jika $r$ hitung $>r$ tabel, instrumen tes yang diujicobakan tersebut dinyatakan valid dengan menggunakan SPSS versi 16, di mana tingkat validitas dapat dilihat pada hubungan antara skor item dan skor total setiap item (nilai $r$ hitung) yang diukur dengan nilai $r$ tabel. Dengan menggunakan distribusi (tabel r) untuk $\alpha=0,05$ dengan derajat kebebasan $(\mathrm{dk}=\mathrm{n}-1=86-1=85)$ sehingga didapat r tabel =0,210 (Wadah, 2016).

Berikut adalah hasil uji validitas dengan menggunakan SPSS versi 16.

Tabel 2. Hasil Uji Validitas

\begin{tabular}{|c|c|c|c|c|}
\hline & $\begin{array}{r}\text { Scale } \\
\text { Mean if Item } \\
\text { Deleted }\end{array}$ & $\begin{array}{c}\text { Scale } \\
\text { Variance if } \\
\text { Item Deleted }\end{array}$ & $\begin{array}{l}\text { Corre } \\
\text { cted Item- } \\
\text { Total } \\
\text { Correlation }\end{array}$ & $\begin{array}{c}\text { Cron } \\
\text { bach's Alpha } \\
\text { if Item } \\
\text { Deleted }\end{array}$ \\
\hline $\begin{array}{ll} & X \\
1 & \\
\end{array}$ & 24.88 & 9.069 & .365 & .728 \\
\hline $2 \quad X$ & 24.87 & 8.160 & .555 & .692 \\
\hline $\begin{array}{ll} & X \\
3 & \\
\end{array}$ & 24.58 & 8.693 & .591 & .693 \\
\hline $4 \quad X$ & 24.59 & 9.068 & .523 & .705 \\
\hline $5 \quad X$ & 25.15 & 8.953 & .441 & .714 \\
\hline $\begin{array}{ll} & X \\
6 & \\
\end{array}$ & 24.72 & 9.356 & .381 & .724 \\
\hline $\begin{array}{ll} & X \\
7 & \end{array}$ & 25.33 & 8.881 & .367 & .729 \\
\hline $\begin{array}{ll} & X \\
8 & \\
\end{array}$ & 24.95 & 9.363 & .334 & .731 \\
\hline $\begin{array}{ll} & X \\
9 & \end{array}$ & 25.38 & 9.180 & .281 & .745 \\
\hline
\end{tabular}

Sumber: Hasil olah data, 2020

Berdasarkan tabel 2. menunjukkan pertanyaan nomor 1 (X1) sampai dengan pernyataan nomor 9 (X9) adalah valid. 
Tabel 3. Hasil Analisis Pengaruh Penghargaan Finansial (PF) terhadap Pemilihan Profesi (Variables in the Equation PF)

\begin{tabular}{ll|l|l|l|l|l|l}
\hline & & .E & ald & f & ig. & $\operatorname{Exp(B)}$ \\
\hline \begin{tabular}{rr|r} 
tep \\
$1^{\text {a }}$
\end{tabular} & $\mathrm{F}$ & 077 & 441 & 030 & & 862 & 1.080 \\
& $\begin{array}{r}\text { onst } \\
\text { ant }\end{array}$ & .463 & 310 & .233 & & 135 & \\
\hline
\end{tabular}

Sumber: Hasil olah Data, 2020

Jika nilai p-value signifikansi yaitu < 0,05 maka menolak hipotesis nol (H0). Tabel hasil olah data di atas adalah tabel utama hasil analisis data regresi logistik. Nilai $\mathrm{p}$ value tidak signifikansi variabel Penghargaan Finansial yaitu 0,135>0,05 maka menerima H0. Dapat disimpulkan bahwa tidak adanya pengaruh yang siginifikan penghargaan finansial untuk memilih profesi alumni sarjana ekonomi syariah di Bogor dengan nilai koefisien yaitu 0,777 dengan nilai signifikansi yang lebih besar dari $a=5 \%$. Variabel tersebut adalah Penghargaan Finansial (Sig=0,135). Model yang terbentuk adalah:

$$
Y_{i}=-0,463+0,077 X_{1}
$$

Hasil di atas dapat diinterpretasikan berdasarkan Odds ratio bahwa jika penghargaan finansial bertambah 1 maka kecenderungan pemilihan profesi menjadi 1,080 kali lipat. Hipotesis pertama pada penelitian menerima $\mathrm{H} 0$ atau penghargaan finansial tidak mempengaruhi alumni sarjana ekonomi syariah untuk memilih profesi. Hasil ini sejalan dengan penelitian Ilyas dan Dary (2017) bahwa menerima H0 atau variabel penghargaan finansial menunjukkan tidak adanya pengaruh minat karir mahasiswa akuntansi menjadi akuntan publik dan non akuntan publik, penyebabnya yaitu karena ada jawaban beberapa responden yang tidak setuju dengan pernyataan mengenai gaji awal yang besar dan kemungkinan inilah yang menyebabkan responden ingin mendapatkan variasi pengalaman kerja terlebih dahulu.

Penelitian Ilyas dan Dary (2017) berbeda dengan penelitian Juliansah dan Suryaputri (2016), berdasarkan penelitian ini bahwa penghargaan finansial dengan pengaruh positif untuk memilih karir profesi. Hal ini dikarenakan penghargaan finansial atau yang disebut 
dengan gaji menjadikan daya tarik yang menjadi pertimbangan minat terhadap pemilihan profesi. Apabila gaji yang diberikan besar, maka minat akan semakin tinggi. Perbandingan pendapatan yang tinggi dan bervariasi dengan pendapatan yang diperoleh dari karir lain yang lebih rendah akan menjadi suatu pertimbangan untuk memilih profesi.

Adapun berdasarkan penelitian ini, penghargaan finansial bukan menjadi hal yang dipertimbangkan untuk memilih profesi, beberapa responden tidak setuju dengan mengutamakan gaji terlebih dahulu. Mayoritas alumni sarjana ekonomi syariah beranggapan bahwa gaji bukan menjadi pilihan utama untuk bekerja, melainkan alumni sarjana ekonomi syariah lebih memilih pengalaman kerja sebagai pilihan utama untuk memilih profesi. Menurut alumni sarjana ekonomi syariah terlebih fresh graduate yang akan terjun ke dunia kerja, calon pekerja harus memiliki pengalaman kerja terlebih dahulu untuk bekerja.

Pengalaman kerja sebagai bentuk persaingan antar alumni sarjana yaitu persaingan antara sesama alumni sarjana ekonomi syariah dan alumni sarjana non ekonomi syariah. Semakin luas pengalaman kerja, maka semakin besar kesempatan alumni sarjana dalam memperoleh pekerjaan.

Tabel 4. Hasil Analisis Pengaruh Pertimbangan Pasar Kerja (PPK) terhadap Pemilihan Profesi (Variables in the Equation PPK)

\begin{tabular}{lr|l|l|l|l|r}
\hline & & E. & ald & f & ig. & $\operatorname{Exp(B)}$ \\
\hline \begin{tabular}{ll|l|l} 
tep \\
$1^{\text {a }}$
\end{tabular} & PK & .869 & 837 & .991 & 025 & 6.481 \\
$\begin{array}{r}\text { onst } \\
\text { ant }\end{array}$ & .616 & 239 & .657 & 010 & \\
\hline
\end{tabular}

Sumber: Hasil olah data, 2020

Nilai signifikansinya yaitu 0,05 , jika $p$-value $<0,05$ maka hipotesis nol (H0) ditolak. Berdasarkan tabel di atas nilai $p$-value variabel pertimbangan pasar kerja yaitu 0,010 artinya H0 ditolak < 0,05. Sehingga, dapat disimpulkan bahwa pertimbangan pasar kerja berpengaruh terhadap keputusan alumni sarjana ekonomi syariah dalam memilih profesi dengan nilai koefisien pengaruh yaitu 1,869 dengan nilai signifikansi yang lebih kecil dari a=5\%. Variabel 
tersebut adalah Pertimbangan Pasar Kerja (Sig=0,010). Model persamaan regresinya yang terbentuk adalah:

$$
Y_{i}=-0,616+1,869 X_{2}
$$

Hasil di atas dapat diinterpretasikan Odds ratio bahwa jika pertimbangan pasar kerja bertambah 1 maka kecenderungan pemilihan profesi menjadi 6,481 kali lipat.Hipotesis kedua pada penelitian menolak $\mathrm{H} 0$ atau pertimbangan pasar kerja mempengaruhi alumni sarjana ekonomi syariah untuk memilih profesi. Hasil ini sejalan dengan penelitian Suindari dan Sari (2018) bahwa adanya pengaruh pertimbangan pasar kerja pada pemilihan karir yang menunjukkan adanya pengaruh positif yang berarti semakin mempertimbangkan jaminan keamanan kerja, lapangan kerja yang mudah diakses atau diketahui dan perluasan akses dengan dunia bisnis maka semakin tinggi minat alumni sarjana. Begitupun hasil penelitian oleh Juliansah dan Suryaputri (2016) bahwa adanya pengaruh positif pertimbangan pasar kerja dalam minat mahasiswa akuntansi memilih profesi sebagai akuntan publik. Hal ini dikarenakan pertimbangan pasar kerja menjadi peluang dari pekerjaan yang akan dipilih. Hal itu sangat berhubungan dengan akses pekerjaan pada masa mendatang.

Hasil penelitian yang dilakukan Suindari dan Sari (2018) berbeda dengan penelitian Ilyas dan Dary (2017), berdasarkan penelitian ini menunjukkan bahwa secara signifikan tidak adanya pengaruh pertimbangan pasar kerja. Beberapa responden tidak setuju dengan lapangan kerja yang mudah diakses, keamanan kerja yang lebih menjamin tidak mudah di PHK, karir yang dapat memperoleh pengetahuan mengenai isu-isu serta memperluas akses dunia bisnis. Hal itu mengindikasikan bahwa minimnya informasi pertimbangan pasar kerja dalam mendapatkan pekerjaan.

Berdasarkan hasil penelitian, menjelaskan bahwa beberapa responden setuju mengenai pertimbangan pasar kerja yang menjadi salah satu pertimbangan dalam memilih profesi. Semakin mudah informasi diakses maka semakin besar peluang alumni sarjana ekonomi syariah untuk mendapatkan pekerjaan. Informasi yang luas memberikan peluang bagi alumni sarjana ekonomi syariah untuk mendapatkan pekerjaan. Pertimbangan lain dalam keputusan memilih profesi yaitu berkaitan dengan jenjang karir, jenjang karir yang dapat memberikan jaminan bagi alumni sarjana ekonomi syariah pada masa mendatang agar terhindar dari pemutusan hubungan kerja. Pekerjaan yang diharapkan nantinya akan menjadi pekerjaan yang 
tetap hingga pensiun. Begitupun dengan lingkungan kerja, tempat kerja yang dapat memberikan keuntungan bagi pekerjanya melalui pengembangan agar dapat menjadi pekerja yang bisa berkompetisi dengan pekerja lain.

\section{KESIMPULAN}

Berdasarkan perolehan hasil analisis dan pembahasan kesimpulan dari penelitian ini bahwa pertimbangan pasar kerja berpengaruh terhadap keputusan alumni sarjana ekonomi syaraih dalam memilih profesi dengan nilai koefisien yaitu 1,869 yang menyatakan bahwa jika penghargaan finansial bertambah 1 maka kecenderungan pemilihan profesi menjadi 6,481 kali lipat. Nilai signifikansi yaitu $0,010(0,010<0,05)$ yang mengindikasikan bahwa adanya pengaruh pertimbangan pasar kerja bagi alumni sarjana ekonomi syariah untuk memilih profesi. Sedangkan variabel penghargaan financial tidak berpengaruh terhadap alumni sarjana ekonomi syariah di Bogor untuk memilih profesi. Hal ini disebabkan alumni sarjana ekonomi syariah lebih memilih pengalaman kerja sebagai pilihan utama untuk memilih profesi dibandingkan dengan penghargaan finansial. Hal ini dikarenakan nilai koefisien yaitu 0,777 yang menyatakan bahwa jika penghargaan finansial bertambah 1 maka kecenderungan pemilihan profesi menjadi 1,080 kali lipat dan nilai signifikansi yaitu $0,135(0,135>0,05)$ yang mengindikasikan bahwa tidak adanya pengaruh penghargaan finansial bagi alumni sarjana ekonomi syariah untuk memilih profesi.

\section{REFERENSI}

Arismutia, S. A. (2017). Pengaruh Penghargaan Finansial Dan Pertimbangan Pasar Kerja Terhadap Minat Mahasiswa Akuntansi Untuk Berkarir Menjadi Akuntan Publik (Studi Pada Mahasiswa Program Studi Akuntansi STIE INABA Bandung). Jurnal Indonesia Membangun, Vol. 16, No. 2. Retrieved from http://jurnal-inaba.hol.es

Deswita, M., \& Astuti, D. (2015). Kompetensi Lulusan Sarjana Ekonomi Syariah Dalam Dunia Kerja (Urgensi dan Harapan). Jurnal Al-hikmah, Vol. 12, No. 2, 148.

Firdaus, S. A. (2017). Pengaruh Inovasi Produk Terhadap Keputusan Nasabah Yang Menabung Di BMT Mu'allimin. Skripsi.

Haryudi. (2018). Gelar Bursa Kerja, Pemkot Bogor Sediakan 1.500 Lowongan Pekerjaan. Retrieved Desember 20, 2019, from Sindo news: https://www.google.com/amp/s/metro.sindonews.com/newsread/1328896/171/gelarbursa-kerja-pemkot-bogor-sediakan-1500-lowongan-pekerjaan-1533753440

Ibda, H. (2018). Strategi Perguruan Tinggi Memajukan Lembaga Keuangan Syariah. Jurnal Equilibrium, Volume 6, Nomor 1, 154. 
Ilyas, F., \& Dary, A. W. (2017). Pengaruh Gender, Penghargaan Finansial Dan Pertimbangan Pasar Kerja Terhadap Minat Mahasiswa Akuntansi Untuk Berkarir Menjadi Akuntan Publik Dan Non Akuntan Publik. Jurnal Akuntansi, Vol. 7, No.1, Hal. 51-60.

Jaya, E. D., Astuti, D. S., \& Harimurti, F. (2018). Pengaruh Penghargaan Finansial, Pelatihan Profesional, Pengakuan Profesional Dan Pertimbangan Pasar Kerja Terhadap Minat Mahasiswa Berkarier Menjadi Akuntan Publik. Jurnal Akuntansi dan Sistem Teknologi Informasi, Vol. 14.

Juliansah, A., \&Suryaputri , R. V. (2016, September). Faktor-faktor Yang Mempengaruhi Pemilihan Karir Sebagai Profesi Akuntan Publik Bagi Mahasiswa Akuntansi. Jurnal Akuntasi Trisakti (e-Journal), Vol. 3, No. 2, Hal 113-134.

Laka, J. K., Sugiarti, \& Harji, Y. (2019, Juni-November). Faktor-Faktor Yang Mempengaruhi Mahasiswa Dalam Pemilihan Karier Sebagai Akuntan Publik (Studi Empiris pada Perguruan Tinggi Swasta di Surakarta). Journal of Islamic Finance and Accounting, Vol. 2, No. 2, 63-80. Retrieved from http://ejournal.iainsurakarta.ac.id/index.php/jifa

Raihan. (2016). Pengambilan Keputusan Dalam Kepemilmpinan Manajmen Dakwah. Jurnal Al-Bayan, Vol. 22 No. 34, 67.

Sholichah, \& Suparman, P. (2017). Faktor-faktor Yang Mempengaruhi Persepsi Mahasiswa Akuntansi Dalam Memilih Profesi Akuntan Publik Di Universitas Gresik. Jurnal Gema Ekonomi, Vol. 06, No. 02, Hal 217 - 234.

Suindari, N. M., \&Sari , A. P. (2018, Oktober). Kinerja Akademik, Pertimbangan Pasar Kerja, Minat Berkarir Akuntan Publik. Junal JMM, Vol. 3, No. 1.

Yusuf, A. M. (2017). Metode Penelitian: Kuantitatif, Kualitatif, Dan Penelitian Gabungan. Jakarta: Prenadamedia Group.

Wadah, R. (2016). Pengaruh Sistem Manajemen Mutu ISO 9001:2008 Terhadap Kinerja Amilin Di Baznas Pusat. Skripsi.

Wicaksono, Y., \& Aisyah, M. N. (2017). Pengaruh Penghargaan Finansial, Lingkungan Kerja, Dan Tipe Kepribadian Terhadap Minat Mahasiswa Akuntansi Untuk Berkarier Menjadi kauntan Publik. Jurnal Fakultas Ekonomi , 7.

Widagdo, R., \& Syafrudin, U. (2016). Peran Perguruan Tinggi Islam Dalam Kontek Ekonom Islam Terhadap Pengembangan Kurikulum Jurusan Perbankan Syari'ah. Jurnal AlAmwal, Volume 8, No. 2, 515. 